\title{
16. CALCAREOUS NANNOFOSSILS FROM THE NORTH ATLANTIC OCEAN, LEG 49, DEEP SEA DRILLING PROJECT
}

\author{
John C. Steinmetz, Rosenstiel School of Marine and Atmospheric Science, University of Miami, Miami, Florida ${ }^{1}$
}

\section{INTRODUCTION}

During Leg 49, 11 holes were drilled at eight sites in the North Atlantic Ocean (Figure 1). Three of the sites (407, $408,409)$ are on the Reykjanes Ridge, south of Iceland, one (410) is near the crest of the Mid-Atlantic Ridge at $45^{\circ}$ North latitude, three $(411,412,413)$ are in or near the FAMOUS area just south of the Azores, and one (414) is on Cruiser-Irving Seamount. The oldest sediments encountered are lower middle Oligocene (Helicopontosphaera reticulata Zone), at Site 407 . Sediments generally contain abundant, well-preserved nannofossils. In those samples containing few nannofossils, large amounts of volcanic sediments and siliceous microfossils account for the dilution. There is little evidence of dissolution. Species are relatively diverse, although many of the indicator species commonly used for zonation in lower latitudes (ceratoliths, discoasters, and sphenoliths) are missing.

\section{METHODS}

Smear slides of the samples were prepared according to the commonly accepted techniques suggested by Bramlette and Sullivan (1961) and Hay $(1961,1965)$. The slides were examined under both cross-polarized and phase-contrast light, using a Zeiss Photomicroscope II at X 1560. The Standard Nannoplankton Zonation of Martini (1971) (see Table 1) was used to make zonal and geological age assignments to the samples, and all nannofossils observed (Table 2) were recorded in the range charts (see Tables 3 through 8). A summary of the zone and age assignments is presented in Figure 2.

\section{Frequency Estimations}

The abundance of nannofossils in deep-sea calcareous sediment is of the order of $10^{6}$ individuals per cubic millimeter (Honjo and Fischer, 1964). Thus, a smear slide prepared with $1 \mathrm{c}: \mathrm{mm}^{3}$ of sediment contains a good sample of the population of nannofossils present. At a magnification of $\times 1560$, between 10 and 100 individual nannofossils are usually visible in sediments containing calcareous and siliceous debris, clay, or volcanic ash. Many nannofossils can be observed, identified, and counted in a few traverses across a glass slide.

All smear slides were scanned for at least ten minutes each. In that time approximately 100 fields of view could be searched. Therefore, between 1000 and 10,000 specimens could be observed. According to population estimates given in the graph of Dennison and Hay (1967), this range of sample size is sufficient to detect a species which comprises

${ }^{1}$ Present address: Department of Marine Science, University of South Florida, St. Petersburg, Florida. between 0.05 and 0.5 per cent of the population, 99 per cent of the time.

Abundance estimates of the total number of taxa present in the assemblage and of individual taxa in the assemblage were made according to the method introduced by Hay (1970, Leg 4). Abundance estimates were recorded in powers of ten because variations among samples, smear slides, and observer proficiency all limit accuracy to orders of magnitude. Individual species counts would insure greater precision in each sample, but the time required for such counting would prove prohibitive, considering the large number of samples and species under study.

The Hay method offers several advantages over actual counting. The estimates span five orders of magnitude. Frequencies of the most abundant species are estimated and recorded immediately, and progressively less abundant species can be estimated. Scanning for the rare species is fairly rapid because the observer can ignore the most common forms already tabulated and concentrate on locating the

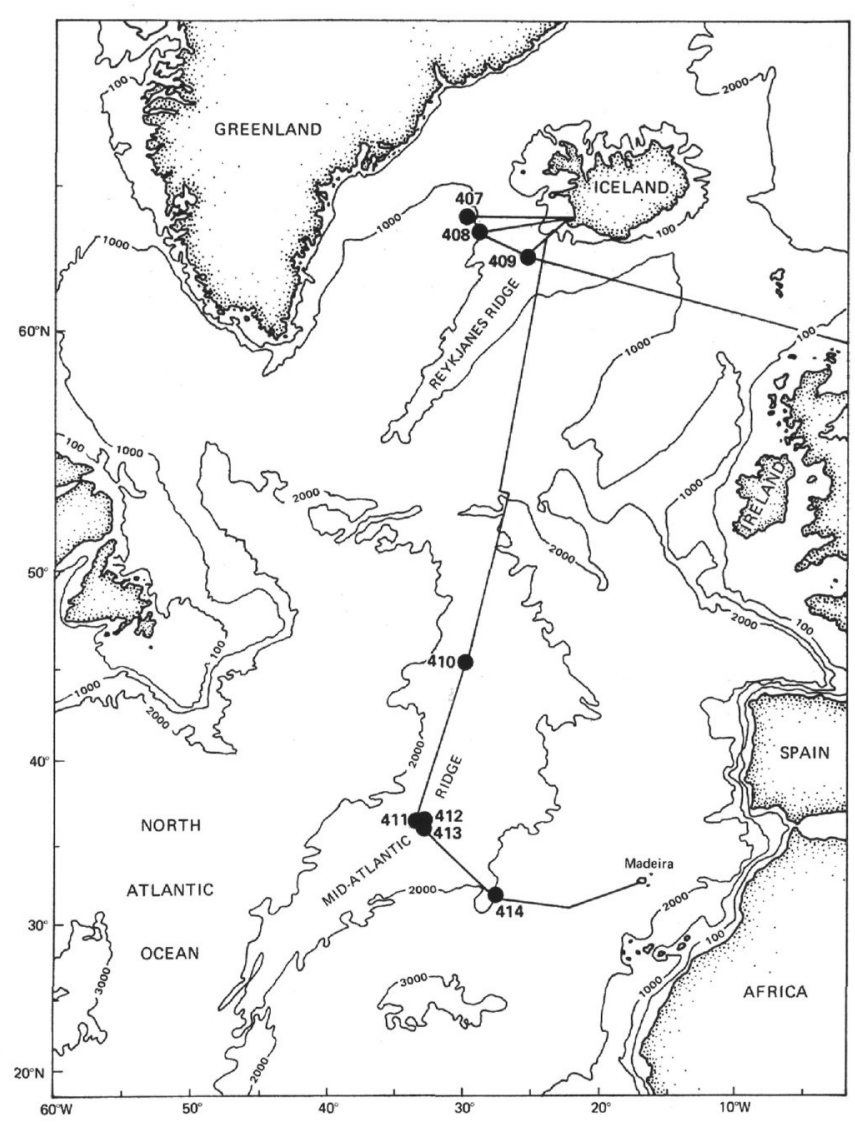

Figure 1. Site locations in the North Atlantic Ocean for DSDP Leg 49. 
TABLE 1

Nannoplankton Zonation of Martini (1971) With Datum Indicators, Covering the Geologic Range of Leg 49 Samples

\begin{tabular}{|c|c|}
\hline Calcareous Nannoplankton Zones & Datum Indicators \\
\hline \multicolumn{2}{|l|}{ NN 21 Emiliania huxleyi Zone } \\
\hline \multicolumn{2}{|l|}{ NN 20 Gephyrocapsa oceanica Zone } \\
\hline \multicolumn{2}{|l|}{ NN 19 Pseudoemiliania lacunosa Zone } \\
\hline \multicolumn{2}{|l|}{ NN 18 Discoaster brouweri Zone } \\
\hline \multicolumn{2}{|l|}{ NN 17 Discoaster pentaradiatus Zone } \\
\hline NN 16 Discoaster surculus Zone & \\
\hline NN 15 Reticulofenestra pseudoumbilica Zone & \\
\hline NN 14 Discoaster asymmetricus Zone & \\
\hline NN 13 Ceratolithus rugosus Zone & \\
\hline NN 12 Ceratolithus tricorniculatus Zone & \\
\hline NN 11 Discoaster quinqueramus Zone & \\
\hline NN 10 Discoaster calcaris Zone & \\
\hline NN 9 Discoaster hamatus Zone & \\
\hline NN 8 Catinaster coalitus Zone & \\
\hline NN 7 Discoaster kugleri Zone & \\
\hline NN 6 Discoaster exilis Zone & \\
\hline NN 5 Sphenolithus heteromorphus Zone & \\
\hline NN 4 Helicopontosphaera ampliaperta Zone & \\
\hline \multicolumn{2}{|l|}{ NN 3 Sphenolithus belemnos Zone } \\
\hline NN 2 Discoaster druggii Zone & \\
\hline NN 1 Triquetrorhabdulus carinatus Zone & \\
\hline NP 25 Sphenolithus ciperoensis Zone & \\
\hline NP 24 Sphenolithis distentus Zone & iperoe \\
\hline NP 23 Sphenolithus predistentus Zone & \\
\hline NP 22 Helicopontosphaera reticulata Zone & \\
\hline
\end{tabular}

${ }^{\mathrm{a}}$ Emiliania annula $($ Cohen $)$ Bukry $=$ Pseudoemiliania lacunosa $($ Kamptner $)$ Gartner

few species of interest (Gartner, 1972). The categories are broad enough that the data collected may be reproduced by different observers, and one can easily compensate for variation between and within samples. The abundance of each species is estimated by the order of magnitude of its frequency per field of view. This is expressed in terms of an exponent to the base ten.

Estimates of abundance are often recorded with the subjective terms "abundant," "common," "frequent," or "few," and "rare" (e.g., Bramlette and Sullivan, 1961). Often authors do not define these terms or assign numerical values to them, so they tend to be confusing. Since Hay proposed his method in 1970, several authors have used it or modifications of it (Martini and Worsley, 1971; Gartner, 1972; Risatti, 1973; Wise, 1973; and Worsley, 1973). Hay's method is employed here with the slight modification, suggested by Gartner (1972), of using suitable letter abbreviations instead of numbers. Species abundances are recorded as the logarithm of the abundance. Table 5 lists the frequency-estimate designations used, and their meaning.
TABLE 2

Calcareous Nannofossil Species Encountered in Leg 49 Cores

Ceratolithus cristatus Kamptner, 1954

Chiasmolithus altus Bukry and Percival, 1971

C. oamaruensis (Deflandre) Hay, Mohler, and Wade, 1966

Coccolithus eopelagicus (Bramlette and Riedel) Bramlette and Sullivan, 196

C. orangensis Bukry, 1971

C. pelagicus (Wallich) Schiller, 1930

C. radiatus Kamptner, 1955

Coronocyclus spp.

Cricolithus jonesi Cohen, 1965

Cyclicargolithus floridanus (Roth and Hay) Bukry, 1971

Cyclococcolithina leptopora (Murray and Blackman) Wilcoxon, 1970

C. macintyrei (Bukry and Bramlette) Bukry, 1973

C. rotula (Kamptner) Wilcoxon, 1970

Cyclolithella annula (Cohen) Mcintyre and Bé, 1967

Cyclolithella annula (Cohen) Mcrntyre and Bè, 1967

Discoaster adamanteus Bramlette and Wilcoxon, 19677

D. asymmetricus Gartner, 19699

D. asymmetricus Gartner, 1969
D. aulakos Gartner, 1967

D. bollii Martini and Bramlette, 1963

D. brouweri Tan Sin Hok, 1927

D. brouweri Tan Sin Hok,
D. calcaris Gartner, 1967

D. calcaris Gartner, 196

D. challengeri Bramlette and Riedel, 1954

D. deflandret Bramlette and Riedel, 1954

D. druggii Bramlette and Wilcoxon, 196

D. exilis Martini and Bramlette, 196

D. extensus Hay, 1967

D. hamatus Martini and Bramlette, 1963

D. icarus Stradner, 1972

D. intercalcaris Bukry, 1971

D. kugleri Martini and Bramlette, 1963

D. obtusus Gartner, 1967

D. pentaradiatus Tan Sin Hok, 1927

D. quinqueramus Gartner, 1969

D. saundersi Hay, 1967

D. surculus Martini and Bramlette, 1963

D. trinidadensis Hay, 1967

D. variabilis Martini and Bramlette, 1963

Discolithina anisotrema (Kamptner) Bramlette and Wilcoxon, 1967

D. callosa Martini, 1969

D. segmenta Bukry and Percival, 1971

D. vigintiforata (Kamptner ex Deflandre) Loeblich and Tappan, 1966

Discosphaera tubifera (Murray and Blackman) Ostenfeld, 1900

Emiliania annula (Cohen) Bukry, 1971 (= Pseudoemiliania lacunosa)

Gephyrocapsa aperta Kamptner, 1963

Gephyrocapsa aperta Kamptner, 1963

G. caribbeanica Boudreaux and Hay, 1967

G. doronicoides (Black and Barn Kamptner, 1943

G. oceanica Kamptner, 1943

H. euphratis (Haq) Bukry, 1973

H. euphratis (Haq) Bukry, 1973
H. granulata Bukry and Percival, 1971

H. granulata Bukry and Percival, 1971
H. intermedia (Martini) Hay and Mohler, 1967

H. intermedia (Martini) Hay and Moh
H. kamptneri Hay and Mohler, 1967

H. kamptneri Hay and Mohler, 1967
H. obliqua (Bramlette and Wilcoxon) Roth and Thierstein, 1972

H. obliqua (Bramlette and
H. recta (Haq) Bukry, 1973

H. recta (Haq) Bukry, 1973
H. sellii Bukry and Percival, 1969

H. sellit Bukry and Percival, 1969
H. wallachi (Lohmann) Boudreaux and Hay, 1969

H. wallachi (Lohmann) Boudreaux and
Isthmolithus recurvus Deflandre, 1954

Isthmolithus recurvus Deflandre, 1954
Orthorhabdus serratus Bramlette and Wilcoxon, 1967

Orthorhabdus serratus Bramlette and Wilcoxon, 1967
Pontosphaera attenuatus (Kamptner) Jafar, 1975

Pontosphaera attenuatus (K
P. discopora Schiller, 1925

P. japonica (Takayama) Nishida, 197

P. multipora (Kamptner) Roth, 1970

P. scutellum Kamptner, 1952

Reticulofenestra bisecta (Hay, Mohler, and Wade) Roth, 1970

R. hillae Bukry and Percival, 1971

R. pseudoumbilica (Gartner) Gartner, 1969

R. scissura Hay, Mohler, and Wade, 1966

R. scrippsae (Bukry and Percival) Roth, 1973

R. umbilica (Levin) Martini and Ritzkowski, 1968

Rhabdosphaera clavigera Murray and Blackman, 1898

$R$. stylifera Lohmann, 1902

Scapholithus fossilis Deflandre, 1954

Scyphosphaera aequatorialis Kamptner, 1963

S. amphora Deflandre, 194

S. apsteini Lohmann, 1902

S. australiensis Rade, 1975

S. cantharelius Kamptner, 1955

S. cantharelius Kamptner,

S. conica Kamptner, 1955

S. cylindrica Kamptner, 195

S. gladstonensis Rade, 1975

S. lagena Kamptner, 1955

S. ventriosa Martini, 1968
Sphenolithus abies Deflandre, 1954

S. belemnos Bramlette and Wilcoxon, 1967

S. belemnos Bramlette and Wicoxon,
S. dissimilis Bukry and Percival, 1971

S. dissimilis Bukry and Percival, 1971

S. heteromorphus Deflandre, 1953
S. moriformis (Brönnimann and Stradner) Bramlette and Wilcoxon, 1967

S. predistentus Bramlette and Wilcoxon, 1967

Syracosphaera histrica Kamptner, 1941

Thoracosphaera deflandrei Kamptner, 1956

T. heimii (Lohman) Kamptner, 1941

T. narena Kamptner, 1967

T. reticulata Jafar, 1975

T. saxea Stradner, 1961

Triquetrorhabdulus carinatus Martini, 1965

T. rugosus Bramlette and Wilcoxon, 1967

Umbilicosphaera mirabilis Lohmann, 1902

Zygrhablithus bijugatus (Deflandre) Deflandre, 195 
TABLE 3

Calcareous Nannofossil Distribution, Site 407

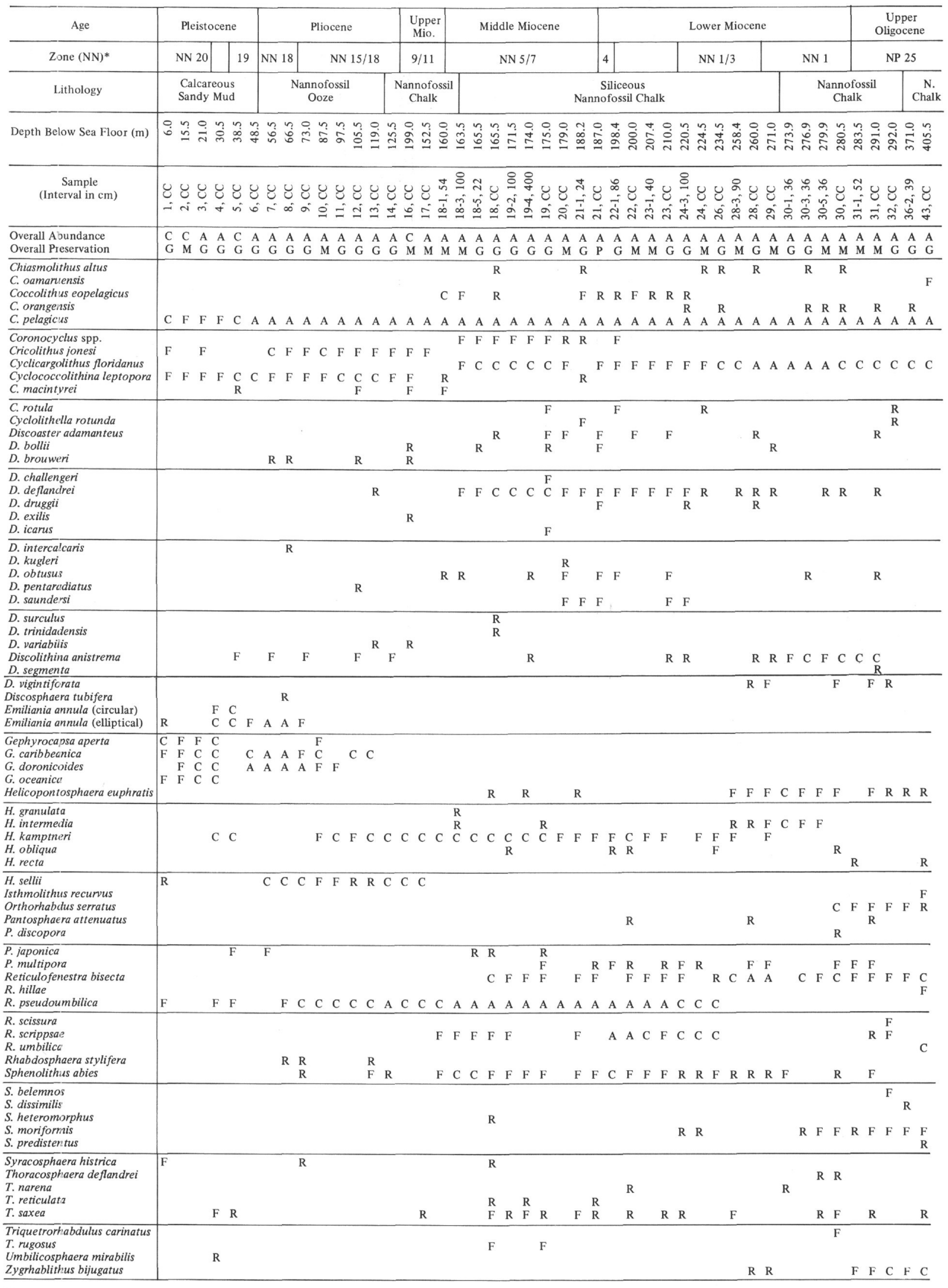

Note: $\mathrm{A}=$ abundant $\mathrm{C}=$ common, $\mathrm{F}=$ few, $\mathrm{R}=$ rare $\mathrm{G}=\operatorname{good}, \mathrm{M}=$ moderate, $\mathrm{P}=$ poor preservation.

*NN numbers refer to Martini's (1971) zones. See Table 1 for corresponding zone name. 
TABLE 4

Calcareous Nannofossil Distribution, Site 408

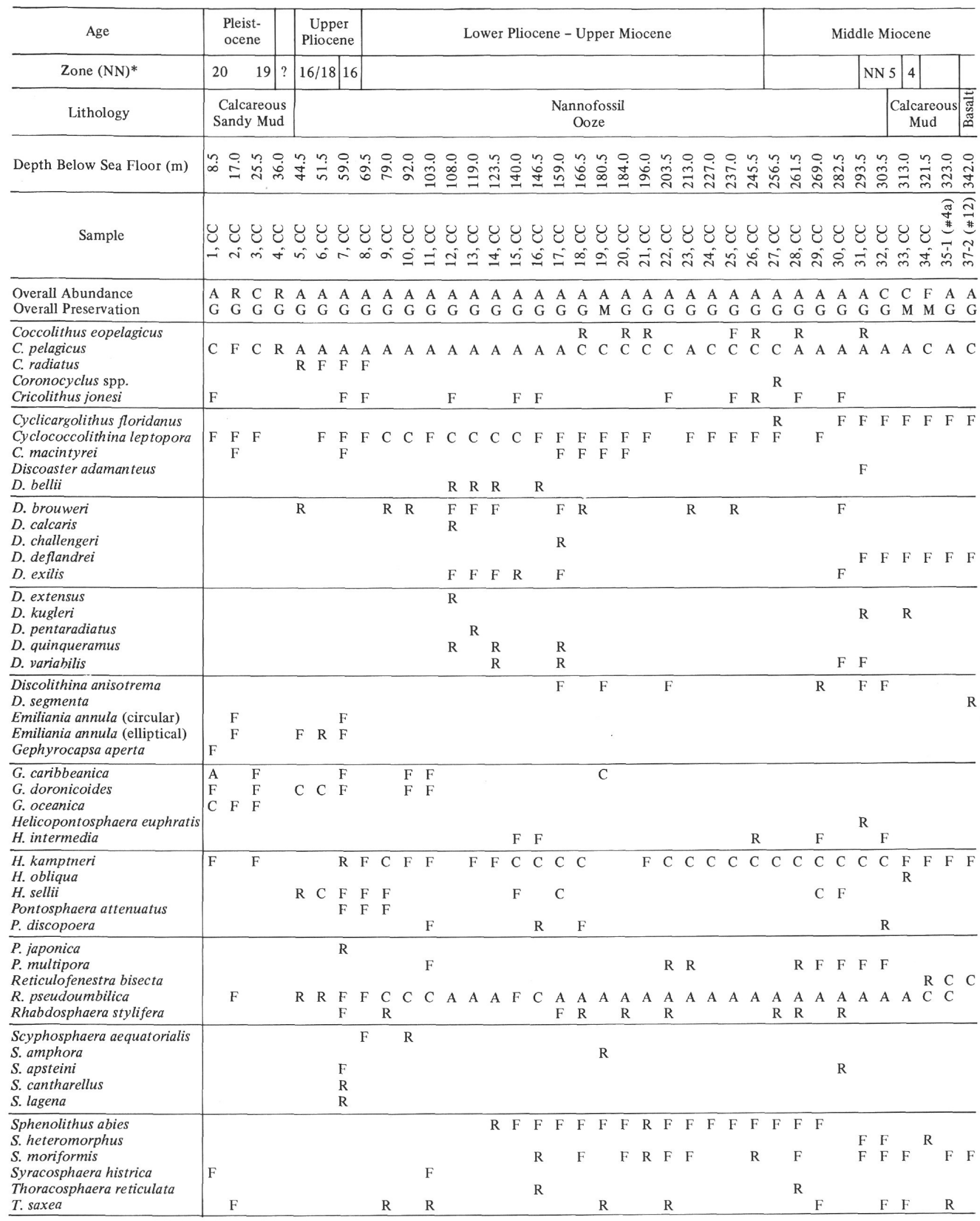

Note: See Table 3 for explanation of symbols.

*NN numbers refer to Martini's (1971) zones. See Table 1 for corresponding zone name. 
TABLE 5

Calcareous Nannofossil Distribution, Site 409

\begin{tabular}{|c|c|c|c|c|c|}
\hline Age & Lower & r Pleist & tocen & & 象 \\
\hline Zone $(\mathrm{NN})^{*}$ & & NN 19 & & & 18 \\
\hline Lithology & \multicolumn{5}{|c|}{$\begin{array}{l}\text { Calcareous } \\
\text { Sandy Mud }\end{array}$} \\
\hline Depth Below Sea Floor (m) & 皃 & $\begin{array}{l}0 \\
\dot{+}\end{array}$ & in & 0 & $\stackrel{\varnothing}{\infty}$ \\
\hline Sample & $\begin{array}{ll}0 & 0 \\
ن & 0 \\
-1 & i\end{array}$ & 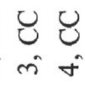 & & & U \\
\hline $\begin{array}{l}\text { Overall Abundance } \\
\text { Overall Preservation }\end{array}$ & $\begin{array}{ll}\mathrm{C} & \mathrm{A} \\
\mathrm{G} & \mathrm{G}\end{array}$ & $\begin{array}{ll}\mathrm{R} & \mathrm{C} \\
\mathrm{M} & \mathrm{G}\end{array}$ & $\begin{array}{l}\mathrm{C} \\
\mathrm{G}\end{array}$ & $\begin{array}{l}\mathrm{C} \\
\mathrm{G}\end{array}$ & $\stackrel{A}{G}$ \\
\hline $\begin{array}{l}\text { Coccolithus pelagicus } \\
\text { Cyclococcolithina leptopora } \\
\text { Discolithina anisotrema } \\
\text { Emiliania annula (circular) } \\
\text { Emiliania annula (elliptical) }\end{array}$ & $\begin{array}{ll}A & \\
F & C \\
R & \\
F & F\end{array}$ & $\begin{array}{ll}\mathrm{F} & \mathrm{A} \\
& \mathrm{F} \\
& \\
& \mathrm{R}\end{array}$ & $\begin{array}{l}\mathrm{R} \\
\mathrm{R} \\
\mathrm{R}\end{array}$ & $\begin{array}{l}\mathrm{A} \\
\mathrm{F}\end{array}$ & $\begin{array}{l}\mathrm{A} \\
\mathrm{F}\end{array}$ \\
\hline $\begin{array}{l}\text { Gephyrocapsa aperta } \\
\text { G. caribbeanica } \\
\text { G. doronicoides } \\
\text { G. oceanica } \\
\text { Helicopontosphaera kamptneri }\end{array}$ & $\begin{array}{ll}C & F \\
C & C \\
F & A \\
R & C\end{array}$ & $\begin{array}{r}\mathrm{A} \\
\mathrm{R} \quad \mathrm{C}\end{array}$ & $\begin{array}{l}\mathrm{F} \\
\mathrm{C} \\
\mathrm{F} \\
\mathrm{R}\end{array}$ & $\mathrm{F}$ & $\mathrm{R}$ \\
\hline $\begin{array}{l}\text { H. sellii } \\
\text { H. wallachi } \\
\text { Pontosphaera japonica } \\
\text { P. scutellum } \\
\text { Syracosphaera histrica } \\
\text { Thoracosphaera heimi }\end{array}$ & $\mid \begin{array}{ll}\mathrm{F} & \\
\mathrm{R} & \\
\mathrm{F} & \mathrm{F} \\
\mathrm{R} & \end{array}$ & $\mathrm{F}$ & $\mathrm{R}$ & $\begin{array}{l}\mathrm{R} \\
\mathrm{R}\end{array}$ & $\mathrm{F}$ \\
\hline
\end{tabular}

Note: Siee Table 3 for explanation of symbols.

*NN numbers refer to Martini's (1971) zone.

See Table 1 for corresponding zone name.

\section{Abundance of Specimens}

10-100 specimens per field of view 1-10 specimens per field of view Single specimen in 1-10 fields of view Single specimen in $10-100$ fields of view Logarithm

Letter Designation

$\begin{array}{rl}+1 & \mathrm{~A} \\ 0 & \mathrm{C} \\ -1 & \mathrm{~F} \\ -2 & \mathrm{R}\end{array}$

The categories listed above correlate roughly with the commonly used categories discussed above: $\mathrm{A}=$ " "abundant," $\mathrm{C}=$ "common," $\mathrm{F}=$ "few," and $\mathrm{R}=$ "rare." Range Charts in the tables use the letter symbols.

\section{Preservation}

The overall preservation of nannofossil assemblages was recorded using one of three letter designations:

$\mathrm{G}=$ Good preservation. Fossils lack evidence of dissolution or overgrowth. All taxa are easily identified.

$\mathbf{M}=$ Moderately good preservation. A majority of the specimens are slightly etched. Fine structures are missing, but no diagnostic changes of form are evident in light microscopy. Rim margins of placoliths are slightly serrate. All taxa may be easily identified. Diversity is normal.

$\mathrm{P}=$ Poor preservation. A majority of the specimens are deeply etched. Identity of many centerless and fragmented specimens is questionable. Diversity is low.

\section{SITE SUMMARIES}

\section{SITE 407}

$63^{\circ} 56.32^{\prime} \mathrm{N}, 30^{\circ} 34.45^{\prime} \mathrm{W}$, water depth $2472 \mathrm{~m}$

Site 407 is on the western flank of the Reykjanes Ridge and lies on magnetic anomaly 13 (36 to $38 \mathrm{~m} . \mathrm{y}$.). Coring was continuous from the mud line through 300.5 meters of sediment into basalt lavas with interlayered sediment down to 458.5 meters sub-bottom. Of this, 183.3 meters of core $(40 \%)$ were recovered. The oldest sediment $405 \mathrm{~m}$ subbottom) is sandy calcareous mud (lower middle Oligocene, upper Helicopontosphaera reticulata Zone).

Four sedimentary units are recognized, on the basis of lithologic characteristics. There are three additional thin zones of intercalated sediment. The first unit ( 0 to $46.3 \mathrm{~m}$ sub-bottom) is a Pleistocene calcareous sandy mud with intervals of calcareous and marly calcareous ooze which contain variable amounts of volcanic ash (up to 20\%). The second unit ( 46.3 to $160.7 \mathrm{~m}$ ) is middle Miocene to Pliocene and composed of a nannofossil ooze (46.3 to 124.0 $\mathrm{m})$ and a nannofossil chalk (124.0-160.7 m). The third unit ( 160.7 to $272.0 \mathrm{~m}$ ) is lower to middle Miocene siliceous nannofossil chalk with an interbedded chalk-volcanic ash zone between 215 and 224.5 meters. The lowermost unit ( 272.0 to $300.5 \mathrm{~m}$ ) is lower Miocene nannofossil chalk (272.0 to $280.0 \mathrm{~m}$ ) and upper Oligocene to lower Miocene nannofossil chalk-basalt pebble gravel.

The three intercalated sediments are characterized as follows: 320.3 to 321.3 meters: upper Oligocene foraminifernannofossil chalk; 329.4 to 331.2 meters: upper Oligocene nannofossil chalk; 405 to 405.4 meters: lower middle Oligocene sandy calcareous mud.

Nannofossil assemblages ranging from upper Pleistocene to lower-middle Oligocene occur in samples recovered at Site 407 (see Table 3). The sediments are generally rich in well-preserved nannofossils, but because of low assemblage diversity and the lack of reliable markers, age assignments to a single zone often are not possible.

Pleistocene assemblages occur in the first five cores. Common in Samples 1, CC to 3, CC are Cyclococcolithina leptopora, Gephyrocapsa aperta, G. caribbeanica, $G$. doronicoides, and $G$. oceanica, indicative of the Gephyrocapsa oceanica Zone (NN 20). Coccolithus pelagicus is present throughout the entire section at Site 407 and predominates in all assemblages observed. Sample $4, \mathrm{CC}$ is probably transitional between Zones NN 19 and NN 20 , because it contains the same assemblage as above, plus common Emiliania annula (= Pseudoemiliania lacunosa). Sample 5,CC is assigned to the Pseudoemiliania lacunosa Zone (NN 19), on the basis of its lack of G. oceanica and the presence of $E$. annula.

The Pliocene/Pleistocene boundary, as established with nannofossils, is between Samples 5,CC and 6,CC, although the last occurrence of Discoaster brouweri is in Sample 7,CC. Samples 7,CC and 8,CC are placed in the upper Pliocene Discoaster brouweri Zone (NN 18) because of the rare occurrences of $D$. brouweri in both. Also present are $C$. leptopora, E. annula, G. doronicoides, and Helicopontosphaera sellii. Cores 9 through 14 contain mixed assemblages of lower and upper Pliocene nannofossils (Zones NN 15 through 18). Reticulofenestra pseudoumbilica and 
TABLE 6

Calcareous Nannofossil Distribution, Site 410

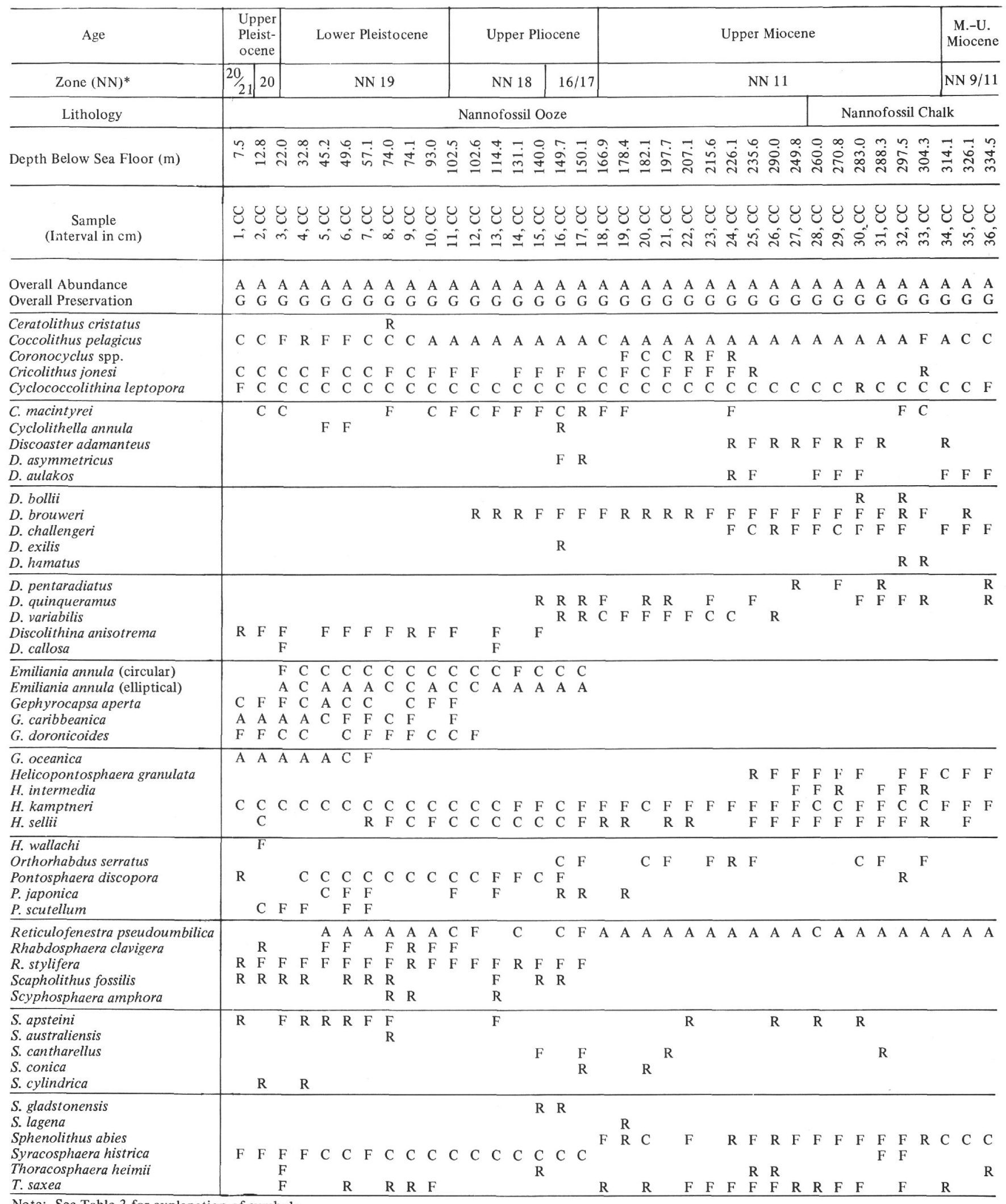

Note: See Table 3 for explanation of symbols.

*NN numbers refer to Martini's (1971) zones. See Table 1 for corresponding zone name. 
TABLE 7

Calcareous Nannofossil Distribution, Hole 412

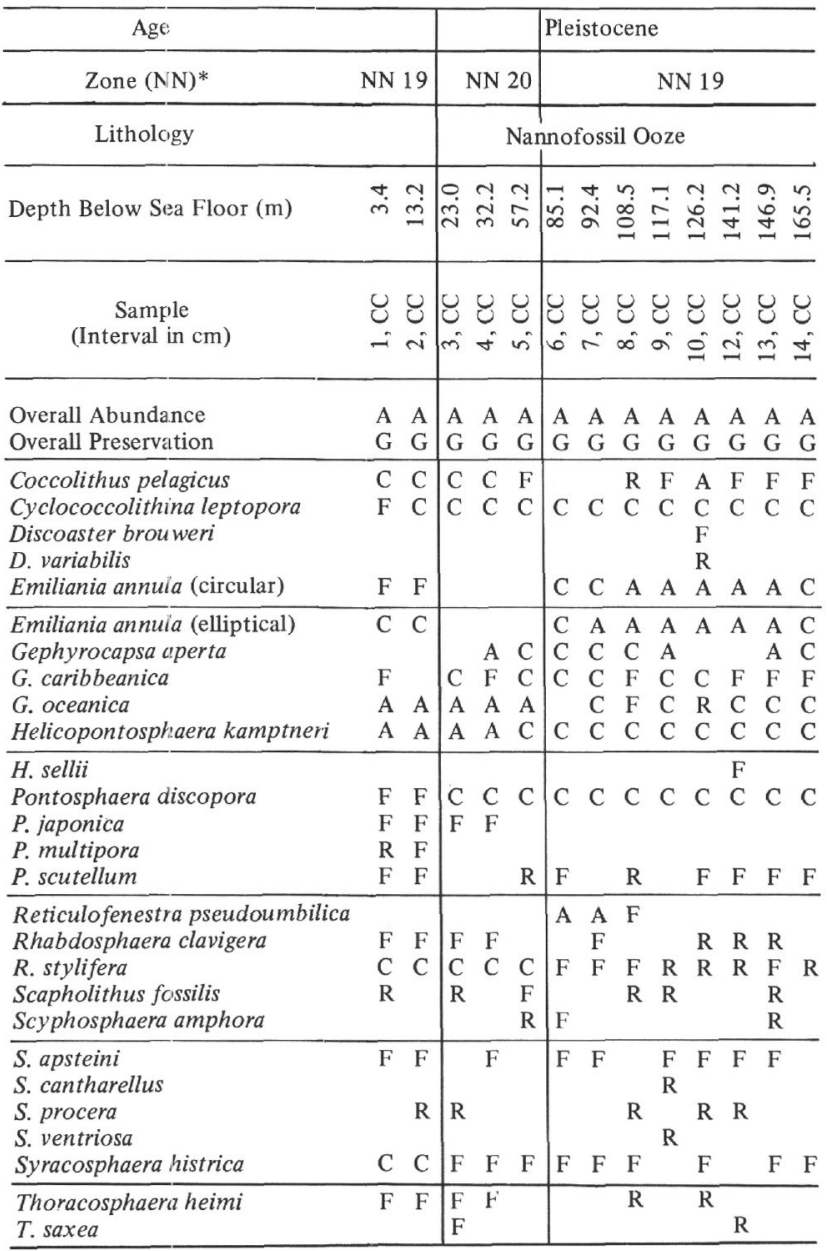

Note: See Table 3 for explanation of symbols.

*NN numbers refer to Martini's (1971) zone. See Table 1 for corresponding zone name.

Helicopontosphaera kamptneri are common. Discoaster pentaradiatus occurs in Sample 12,CC, Discoaster variabilis in Sample 13,CC; highest occurrences of each are Zones NN 17 and NN 16, respectively. G. caribbeanica is anomalously common in Samples 9,CC, 10,CC, 12,CC, and $13, \mathrm{CC}$. This suggests downhole contamination. No sediment was recovered in Core 15.

Samples 16, CC and 17, CC contain nannofossils indicative of the upper Miocene (Zones NN 9 to NN 11): $H$. kamptneri, $H$. sellii, $R$. pseudoumbilica, Discoaster bollii, $D$. brouweri, D. exilis, and $D$. variabilis.

A hiatus exists between Samples 17, CC and 18, CC, because Samples 18, CC and 19, CC are placed in the upper middle Miocene Discoaster kugleri Zone (NN 7). $R$. pseudoumbilica is present in great abundance, together with Discoaster adamanteus, C. challengeri, D. deflandrei, Coronocyclus sp., Cyclicargolithus floridanus, Sphenolithus abies, and Triquetrorhabdulus rugosus. The assemblage in Sample 20, CC is rather mixed and suggests Zones NN 5 to NN 7, the middle Miocene.

Lower Miocene nannofossil assemblages occur in Sam-
TABLE 8

Calcareous Nannofossil Distribution, Hole 412A

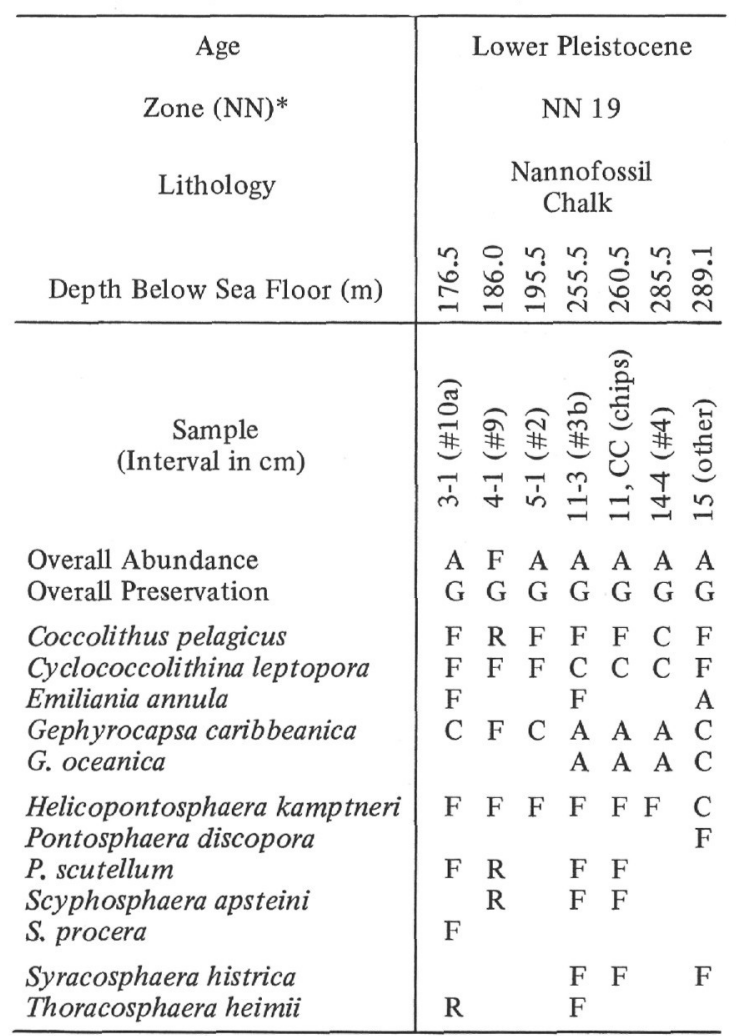

Note: See Table 3 for explanation of symbols.

*NN number refers to Martini's (1971) zone. See Table

1 for corresponding zone name.

ples $21, \mathrm{CC}$ to $30, \mathrm{CC}$. Sample 21,CC contains $D$. adamanteus, D. bollii, D. deflandrei, D. druggii, D. obtusus, D. saundersi, $C$. floridanus, $R$. pseudoumbilica, and $S$. abies. It is assigned to the upper lower Miocene Helicopontosphaera ampliaperta Zone (NN 4). Sample 22,CC contains a mixed lower Miocene assemblage. The great abundance of Reticulofenestra scrippsae is notable. Samples 23,CC, $24, \mathrm{CC}, 26, \mathrm{CC}$, and $28, \mathrm{CC}$ (no recovery in $25, \mathrm{CC}$ and $27, \mathrm{CC}$ ) are assigned to the lower Miocene (NN1 to NN 3) on the basis of the following: Chiasmolithus altus, Cyclicargolithus floridanus, $R$. pseudoumbilica, and $R$. scrippsae.

The Triquetrorhabdulus carinatus Zone (NN 1) is distinguished in Samples 29,CC and 30,CC, as indicated particularly by Discolithina vigintiforata, C. floridanus, Reticulofenestra bisecta, Orthorhabdus serratus, Triquetrorhabdulus carinatus, and Zygrhablithus bijugatus.

Samples 31,CC, 32,CC and 36-2, $39 \mathrm{~cm}(34, \mathrm{CC}$ is barren) contain uppermost Oligocene assemblages from the Sphenolithus ciperoensis Zone (NP 25). Present are Helicopontosphaera recta, $C$. floridanus, $D$. vigintiforata, $O$. serratus, $R$. bisecta, $S$. moriformis, and $Z$. bijugatus.

About 100 meters of basalt were encountered next. Recovery in Core 43 was limited to the core catcher sample, containing sandy calcareous mud. Nannofossils present include Chiasmolithus oamaruensis, Helicopontosphaera cf. $H$. recta, Isthmolithus recurvus, Reticulofenestra hillae, Sphenolithus predistentus, $S$. moriformis, and Z. bijugatus. 


\begin{tabular}{|c|c|c|c|c|c|c|c|c|c|c|c|}
\hline \multirow{2}{*}{\multicolumn{2}{|c|}{$\begin{array}{l}\text { Chronostrati- } \\
\text { graphic Unit }\end{array}$}} & \multirow{2}{*}{\multicolumn{2}{|c|}{ Calcareous Nannofossil Zone }} & \multicolumn{8}{|c|}{ Sites } \\
\hline & & & & 407 & 408 & 409 & 410 & 411 & $411 \mathrm{~A}$ & 412 & $412 \mathrm{~A}$ \\
\hline \multirow{3}{*}{\multicolumn{2}{|c|}{ 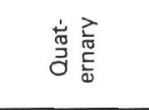 }} & Emiliania huxleyi & NN21 & \multirow{2}{*}{$1-3$} & \multirow{2}{*}{1} & & \multirow{2}{*}{$1-2$} & & \multirow{2}{*}{1} & & \\
\hline & & Gephyrocapsa oceanica & NN20 & & & & & & & 3-5 & \multirow{2}{*}{$3-15$} \\
\hline & & Pseudoemiliania lacunosa & NN19 & $4-5$ & $2-3$ & 1.6 & 3-11 & 1 & 2 & $1-2,6-14$ & \\
\hline \multirow{5}{*}{ 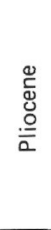 } & \multirow{2}{*}{ 这 } & Discoaster brouweri & NN18 & $6-8$ & \multirow[b]{2}{*}{$5-7$} & 7 & $12-15$ & & & & \\
\hline & & Discoaster pentaradiatus & NN17 & \multirow{4}{*}{$9-14$} & & & $16-17$ & & & & \\
\hline & \multirow{3}{*}{ 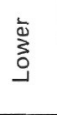 } & $\begin{array}{l}\text { Discoaster surculus } \\
\text { Reticulofenestra pseudoumbilica }\end{array}$ & NN16 & & \multirow{4}{*}{$8-11$} & & & & & & \\
\hline & & Discoaster asymmetricus & NN14 & & & & & & & & \\
\hline & & Ceratolithus rugosus & NN13 & & & & & & & & \\
\hline \multirow{12}{*}{ 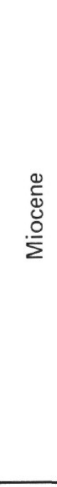 } & \multirow{3}{*}{ 产 } & Ceratolithus tricarniculatus & NN12 & & & & & & & & \\
\hline & & Discoaster quinqueramus & NN11 & & $12-14$ & & $18-33$ & & & & \\
\hline & & Discoaster calcaris & NN10 & $16-17$ & \multirow{5}{*}{$15-30$} & & $34-36$ & & & & \\
\hline & \multirow{5}{*}{$\frac{\frac{0}{\overline{0}}}{\frac{0}{2}}$} & Discoaster hamatus & NN9 & & & & & & & & \\
\hline & & Catinaster coalitus & NN8 & & & & & & & & \\
\hline & & Discoaster kugleri & NN7 & $18-19$ & & & & & & & \\
\hline & & Discoaster exilis & NN6 & 20 & & & & & & & \\
\hline & & Sphenolithus heteromorphus & NN5 & & $31-33$ & & & & & & \\
\hline & \multirow{4}{*}{ 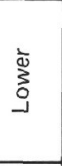 } & Helicopontosphaera ampliaperta & NN4 & 21 & 34 & & & & & & \\
\hline & & Sphenolithus belemnos & NN3 & \multirow{2}{*}{$23-28$} & \multirow[t]{8}{*}{35,37} & & & & & & \\
\hline & & Discoaster druggii & NN2 & & & & & & & & \\
\hline & & Triquetrorhabdulus carinatus & NN1 & $29-30$ & & & & & & & \\
\hline \multirow{5}{*}{ 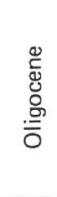 } & \multirow{2}{*}{$\begin{array}{l}\frac{\mathrm{d}}{2} \\
\frac{0}{2} \\
\end{array}$} & Sphenolithus ciperoensis & NP25 & 31.36 & & & & & & & \\
\hline & & Sphenolithus distentus & NP24 & & & & & & & & \\
\hline & $\dot{\Sigma}$ & Sphenolithus predistentus & NP23 & & & & & & & & \\
\hline & \multirow{2}{*}{ 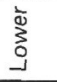 } & Helicopontosphaera reticulata & NP22 & 43 & & & & & & & \\
\hline & & Ericsonia subdisticha & NP21 & & & & & & & & \\
\hline
\end{tabular}

Figure 2. Zonal and geologic age assignments of Leg 49 cores, based on calcareous nannofossils. (The numbers assigned to zonal intervals are core numbers of samples examined.)

This assemblage suggests the lower middle Oligocene upper Helicopontosphaera reticulata Zone (NP 22). The remaining cores are basalt.

\section{SITE 408}

\section{$63^{\circ} 22.63^{\prime} \mathrm{N}, 28^{\circ} 54.71^{\prime} \mathrm{W}$, water depth $1624 \mathrm{~m}$}

Site 408 is on the west flank of the Reykjanes Ridge on magnetic anomaly 6 (about 20 m.y.). It was continuously cored through 321.6 meters of sediment, then into basalt lavas with some interlayered sediment down to 361 meters; 220 meters $(61 \%)$ were recovered. The oldest sediment is lower Miocene nannofossil ooze interlayered with basalt at 344.3 meters.

Three major sedimentary units may be distinguished on the basis of lithologic characteristics. The first unit $(0$ to $38.0 \mathrm{~m}$ sub-bottom) is a Pleistocene calcareous sandy mud with some graded turbidite layers. The second unit (38.0 to $294.5 \mathrm{~m}$ ) is middle Miocene to Pliocene nannofossil ooze. The lowermost unit ( 294.5 to $323.6 \mathrm{~m}$ ) is lower to middle Miocene calcareous mud grading to basalt gravel above the sediment basalt contact.

The nannofossils at Site 408 (see Table 5) are abundant and well preserved. The plentiful occurrence of biogenic silica (i.e., sponge spicules, diatoms, and radiolarians); core-catcher samples 23 through 29) and volcanic ash (core-catchers samples 1 through 4 and 32 through 35) cause some dilution of nannofossils, but enough are usually present to establish the characteristics of the assemblage. Age determinations here are not considered rigorous owing to the low assemblage diversity and lack of reliable indicators (in most cases discoasters, ceratoliths, and sphenoliths) at this high latitude. All observations reported here refer only to core-catcher (CC) samples unless otherwise noted.

Samples 1,CC through 3,CC (8.6 to $25.6 \mathrm{~m}$ ) are Pleistocene (Zones NN 19 and 20), and are characterized by $C$. pelagicus, C. leptopora, Gephyrocapsa spp., and Syracosphaera histrica. Gephyrocapsa oceanica is present in these cores and first occurs in Sample 3,CC, thus establishing the lower boundary of the Pseudoemiliania lacunosa Zone (NN 19). Emiliania annula last occurs in Sample 2,CC, which places the lower/upper Pleistocene boundary (between NN 19 and NN 20) between Samples 1,CC and 2,CC. Sample $4, \mathrm{CC}(36.2 \mathrm{~m})$ is essentially barren, and yields only rare occurrences of $C$. pelagicus among the volcanic ash.

Samples 5,CC through 7,CC (44.4 to $59.2 \mathrm{~m}$ ) are designed upper Pliocene (Zones NN 16/18) on the basis of the assemblage comprising $C$. pelagicus, C. leptopora, $E$. annula, $S$. histrica, and $H$. sellii. Discoaster brouweri occurs rarely in Sample 5,CC, and, together with the last occurrence of $H$. sellii, defines the upper limit of the uppermost 
Pliocene Discoaster brouweri Zone (NN 18). The first occurrence of $E$. annula, in Sample 7,CC, defines the lower limit of the upper Pliocene Discoaster surculus Zone (NN 16).

Samples $8, \mathrm{CC}$ through $26, \mathrm{CC}$ (69.3 to $245.4 \mathrm{~m}$ ) are characterized by assemblages transitional from the lower Pliocene to the upper Miocene. No good markers are present that would allow for subdivision of this long interval. The taxa present are $C$. pelagicus, $C$. leptopora, $H$. kamptneri, H. sellii, R. pseudoumbilica, and S. abies. Discoasters $D$. bollii, $D$. challengeri, $D$. exilis, and $D$. variabilis occur sporadically and rarely throughout the interval. The lower limit of the upper Miocene at Sample 26,CC is determined by the occurrence of middle Miocene species in Sample 27,CC (256.6 m), namely, Coronocyclus sp. and Cyclicargolithus floridanus. Middle Miocene species may range farther up in the core, and because of their rarity were not noted.

Samples 28,CC through $30, \mathrm{CC}$ (261.6 to $282.3 \mathrm{~m}$ ) contain unremarkable middle Miocene taxa: $C$. pelagicus, $C$. leptopora, $H$. intermedia, $H$. kamptneri, $R$. pseudoumbilica, S. abies, and S. moriformis. Samples 31,CC through $32, \mathrm{CC}(293.4$ to $303.5 \mathrm{~m})$ fall in the middle Miocene Sphenolithus heteromorphus Zone (NN 5), as indicated by an assemblage the same as above except for a particularly notable abundance of $S$. heteromorphus. Sample 33,CC (313.2 $\mathrm{m}$ is middle Miocene. Reticulofenestra bisecta occurs in Sample 34,CC (321.2 m) and establishes it as the Helicopontosphaera ampliaperta Zone (NN 4).

Samples from Section 35-1, Piece \# 4a (323 m) and Section 37-2, Piece \#12 (345 m) were obtained from chalks on basalt substrates. Neither chalk sample shows evidence of baking, and nannofossils are fairly abundant and in good condition among the ash matrix. Both contain assemblages characteristic of the lower Miocene: $C$. floridanus, C. pelagicus, D. deflandrei, H. kamptneri, $R$. bisecta, $R$. pseudoumbilica, and $S$. moriformis.

\section{SITE 409}

\section{$62^{\circ} 36.98^{\prime} \mathrm{N}, 25^{\circ} 57.17^{\prime} \mathrm{W}$, water depth $832 \mathrm{~m}$}

Site 409 is in the western crestal region of the Reykjanes Ridge. It is in the Matuyama reversed magnetic stripe near the Gauss boundary (anomaly 2') . A hard sea floor of turbidite sand required washing down to 24.5 meters. Coring was continuous from there through 55.5 meters of sediment, then through basalt to 319 meters; 88.4 meters (30\%) were recovered. The oldest sediment is upper Pliocene sandy calcareous mud $(81.5 \mathrm{~m})$.

Two major sedimentary units are distinguished on the basis of their lithologic characteristics and especially their sedimentary structures. The upper unit $(24.5$ to $58.9 \mathrm{~m})$ is lower Pleistocene calcareous sandy mud containing several turbidite units. The lower unit (58.9 to $81.5 \mathrm{~m})$ is upper Pliocene-lower Pleistocene mostly structureless calcareous sandy mud.

The nannofossils at Site 409 range from upper Pliocene to lower Pleistocene (see Table 5). All observations reported here were made on core-catcher samples, unless otherwise noted. All samples except 3,CC contain common to abundant, well-preserved nannofossils; $3, \mathrm{CC}$ is virtually barren of calcareous material.
Samples $1, \mathrm{CC}$ to $6, \mathrm{CC}$ contain an assemblage of nannofossils characteristic of the lower Pleistocene Pseudoemiliania lacunosa Zone (NN 19): abundant $C$. pelagicus, common to abundant $G$. caribbeanica, $G$. doronicoides, and $G$. oceanica, and occurrences of $C$. leptopora, E. annula, and $H$. kamptneri. Samples 2,CC and $5, \mathrm{CC}$ are peculiar in that $C$. pelagicus is absent; this species usually dominates all assemblages from Miocene to Recent in the previous sites (407 and 408) at this latitude.

Sample 7,CC contains nannofossil assemblage of the upper Pliocene Discoaster brouweri Zone (NN 18). Present are abundant $C$. pelagicus, common $E$. annula, and $C$. leptopora. Notably absent are Gephyrocapsa spp. The Pliocene/Pleistocene boundary, as established with nonnofossils, is placed by the first occurrence of Gephyrocapsa spp. in Sample 6,CC (67.0 m).

Minor amounts of chalk occur approximately 50 meters below the first basalt. Section 1-13, Piece \# 13, and Section 2-13, Piece \# 1 (approximately $130 \mathrm{~m}$ sub-bottom) contain rare, poorly preserved nannofossils in an ash matrix. No species determinations were possible.

\section{SITE 410 \\ $45^{\circ} 31.51^{\prime} \mathrm{N}, 2^{\circ} 28.56^{\prime} \mathrm{W}$, water depth $2975 \mathrm{~m}$}

Site 410 is on magnetic anomaly 5 (about 10 m.y.) on the west side of the Mid-Atlantic Ridge crest. Hole 410 was cored continuously through 340 meters of sediment, and ended in basalt at 387.5 meters; 65 per cent of the sediment drilled was recovered. The oldest sediment is upper Miocene nannofossil chalk $(340 \mathrm{~m})$. Three sedimentary units are recognized by their lithologic characteristics. The uppermost unit (0 to $36.0 \mathrm{~m}$ ) is Pleistocene, mostly nannofossil ooze with interlayered calcareous muds and marly nannofossil ooze. The middle unit $(36.0$ to $245.0 \mathrm{~m})$ is upper Miocene to Pleistocene nannofossil ooze. The lowermost unit ( 245.0 to $340.0 \mathrm{~m}$ ) is upper Miocene nannofossil chalk with minor layers of interbedded nannofossil ooze. A thin basaltic sand overlies the basalt basement.

Hole 410A is offset 108 meters from the beacon of Hole 410. It was washed down through the sediment to the sediment/basalt contact $(333.4 \mathrm{~m})$, where one core was taken. The sediment is upper Miocene.

\section{Hole 410}

Sediments in Hole 410 can be characterized here as well-preserved nannofossil oozes. All observations reported here were made only on core-catcher (CC) samples unless otherwise noted (see Table 6).

Samples $1, \mathrm{CC}$ and $2, \mathrm{CC}$ (12.8 to $7.5 \mathrm{~m}$ ) contain nannofossil assemblages of the upper Pleistocene. Abundant $G$. aperta, G. caribbeanica, and $G$. oceanica, together with common $C$. pelagicus and $H$. kamptneri, account for most of the coccoliths present. Also evident were Pontosphaera scutellum, Rhabdosphaera clavigera, and $R$. stylifera.

Samples 3,CC through $11, C C$ ( 22.0 to $102.5 \mathrm{~m}$ ) belong to the lower Pleistocene Pseudoemiliania lacunosa Zone (NN 19). They commonly contain $C$. pelagicus, C. leptopora, E. annula, Gephyrocapsa spp., H. kamptneri, Pontosphaera discopora, and $R$. stylifera. Samples 5,CC through $11, \mathrm{CC}$ (45.2 to $102.5 \mathrm{~m}$ ) contain anomalously abundant $R$. 
pseudoumbilica, which usually does not appear this high in the section; this suggests some mixing of PliocenePleistocene assemblages, possibly caused by turbidites. The Pliocene/Pleistocene boundary is between Samples 11,CC and $12, \mathrm{CC}$, as indicated by the highest occurrence of $D$. brouweri in Sample 12,CC (102.6 m) and 12,CC, as indicated by the highest occurrence of $D$. brouweri in Sample $12, \mathrm{CC}(102.6 \mathrm{~m})$ and the first occurrence of barred Gephyrocapsa (G. aperta and G. caribbeanica) in Sample $11, \mathrm{CC}(102.5 \mathrm{~m})$.

Samples $12, \mathrm{CC}$ through $17, \mathrm{CC}(102.6$ to $150.1 \mathrm{~m})$ are upper Pliocene. They contain $C$. pelagicus, $E$. annula, $H$. kamptneri, $H$. sellii, $R$. pseudoumbilica, and various discoasters. Samples 12,CC through $15, C C(102.6$ to $140.0 \mathrm{~m})$ are placed in the Discoaster brouweri Zone (NN 18), since they also contain $D$. asymmetricus, $D$. exilis, and $D$. variabilis, and indicate upper Pliocene Zones NN 16 and NN 17. A hiatus exists between Samples 17,CC (150.1 m) and 18,CC (166.9 m), where upper Pliocene sediments rest directly on upper Miocene sediments. Samples 18,CC through $29, \mathrm{CC}$ (166.9 to $270.8 \mathrm{~m}$ ) are placed in the Discoaster quinqueramus Zone NN 11 (upper Miocene). They contain C. pelagicus, C. leptopora, Coronocyclus spp., Helicopontosphaera spp., D. brouweri, D. quinqueramus, $D$. variabilis, and $R$. pseudoumbilica.

Limestone fragments within the basalt breccia of Section $37-1$, and in Sample 37,CC (340 to $341 \mathrm{~m}$ ) contain the following nannofossils: $C$. pelagicus, $H$. kamptneri, $R$. pseudoumbilica, and $S$. abies. These suggest the upper Miocene.

\section{Hole 410A}

Only one core was recovered at Hole 410A. Sediments at the sediment/basalt contact, Sample 410A-1-6, $86 \mathrm{~cm}$ (333.4 m sub-bottom), are of the upper Miocene Discoaster quinqueramus Zone (NN 11), and contain D. pelagicus, $C$. leptopora, $H$. kamptneri, $H$. sellii, R. pseudoumbilica, $S$. abies, and $D$. variabilis.

\section{SITE 411}

\section{$36^{\circ} 45.97^{\prime} \mathrm{N}, 33^{\circ} 23.30^{\prime} \mathrm{W}$, water depth $1935 \mathrm{~m}$}

Site 411 is on the west terrace in the rift valley of the Mid-Atlantic Ridge crest, in the FAMOUS area. It lies on the old side of the Jaramillo magnetic stripe, and is the youngest site drilled to date by DSDP ( $1 \mathrm{~m}$.y. old). Hole 411 was washed down to the sediment/basalt contact at 74 meters. Only one sediment core was recovered, also representing the oldest sediment at the site. It is a Pleistocene foraminiferal pteropod sand.

Hole 411A is offset 17 meters from Hole 411. Three cores were cut between the mudline and 37 meters. They are all Pleistocene nannofossil-foraminifer ooze.

\section{Hole 411}

Hole 411 was sampled for nannofossils only from the material recovered above the basalt in Core 1. Abundant well-preserved nannofossils were recovered in this sediment. The assemblage indicates the lower Pleistocene
Pseudoemiliania lacunosa Zone (NN 19): Gephyrocapsa spp., C. pelagicus, C. leptopora, E. annula, and $H$. kamptneri.

\section{Hole 411A}

Hole 411A was sampled for nannofossils only in 1,CC and 2,CC. Sample 1,CC (74.5 m) contains an upper Pleistocene assemblage (Zone NN 20/21) consisting of Gephyrocapsa spp., H. kamptneri, C. pelagicus, C. leptopora, and $R$. clavigera. Sample $2, \mathrm{CC}(82.7 \mathrm{~m})$ contains a lower Pleistocene assemblage (Zone NN 19) consisting of Gephyrocapsa spp., C. pelagicus, C. leptopora, E. annula, and $H$. kamptneri.

\section{SITE 412}

\section{$36^{\circ} 33.74^{\prime} \mathrm{N}, 33^{\circ} 09.96^{\prime} \mathrm{W}$, water depth $2609 \mathrm{~m}$}

Site 412 is about a mile south of the north wall of Fracture Zone $\mathrm{B}$ and east of the ridge crest in the FAMOUS area. Hole 412 was continuously cored to basement, at 165.5 meters, except for two washed intervals (32.5 to $51.5 \mathrm{~m}$ and 61 to $80 \mathrm{~m}$ ); recovery was about 67 per cent. The oldest sediment recovered is Pleistocene nannofossil chalk. In general, the sediment in Hole 412 is nannofossil ooze with down-core gradations in total carbonate content and in the amounts of foraminifers and biogenic silica (see Table 7).

Hole 412A was washed down to basement at 163 meters. Nannofossil chalk and small amounts of ooze are present as intercalated sediments within the basalt in Cores $3,11,12$, and 14 (see Table 8).

All sediments recovered at Site 412 can be characterized here as nannofossil oozes in which abundance and preservation of the taxa are generally good. The following ages were determined only on core-catcher (CC) samples unless otherwise noted.

\section{Hole 412}

All sediments examined contain common to abundant $C$. pelagicus, C. leptopora, Gephyrocapsa spp., H. kamptneri, and $P$. discopora. Rhabdosphaera clavigera, $R$. stylifera, Scyphosphaera apsteini, and Syracosphaera histrica occur consistently, but in lesser amounts. Emiliania annula is common to abundant in all samples except $3, \mathrm{CC}, 4, \mathrm{CC}$, and $5, \mathrm{CC}$, where it is absent. The absence of $E$. huxleyi rules out the presence of any uppermost Pleistocene or Holocene sediments of the Emiliania huxleyi Zone (NN 21) in the samples examined. Samples 3,CC, 4,CC, and 5,CC (23.0 to $57.2 \mathrm{~m}$ ) are interpreted as upper Pleistocene, Gephyrocapsa oceanica Zone (NN 20), on the basis of $G$. aperta, G. caribbeanica, and $G$. oceanica, and the absence of $E$. annula.

Samples 1,CC, 2,CC, and 6,CC through 14,CC (3.4, 13.2 , and 85.1 to $165.7 \mathrm{~m}$, respectively) are lower Pleistocene, Pseudoemiliania lacunosa Zone (NN 19), indicated by the presence of the above-mentioned gephyrocapsids and the presence of $E$. annula. Discoaster brouweri and $C$. variabilis occur in small numbers in Sample 10,CC (126.2 m), suggesting the presence of some Pliocene sediment, possibly introduced by slumping. 


\section{Hole 412A}

Nannofossils recovered at Hole 412A were obtained from indurated crusts on basalt fragments. All samples contain lower Pleistocene assemblages. The samples following were dated from the nannofossils present.

Core
3
4
5
11
11
14
15

Section
1
1
1
3
CC
4
Other

Piece \#
10A
9
2
$3 \mathrm{~B}$
-
4
-

Typically present are C. pelagicus, C. leptopora, E. annula, Gephyrocapsa spp., H. kamptneri, and Scyphosphaera spp. No discoasters were observed.

\section{SITE 413}

\section{$36^{\circ} 32.59^{\prime} \mathrm{N}, 3^{\circ} 10.50^{\prime} \mathrm{W}$, water depth $2598 \mathrm{~m}$}

Site 413 is on the south side of Fracture Zone B, east of the ridge crest in the FAMOUS area, 1.3 miles south of Site 412. The hole was washed down to basement at 110 meters sub-bottom. The oldest sediments recovered are Pleistocene basalt-limestone breccias $(134.0 \mathrm{~m})$.

Nannofossils from Hole 413 were examined from three cores. Sample 1-1, 10-11 cm (about $110 \mathrm{~m}$ sub-bottom) consists of basaltic and carbonate sand and silt. Abundant well-preserved nannofossils are present. The assemblage indicates the lower Pleistocene Pseudoemiliania lacunosa Zone (NN 19): C. pelagicus, E. annula, Gephyrocapsa spp., $H$. kamptneri, and $P$. discopora. Section 2-1, Piece \#6 (about $115 \mathrm{~m}$ sub-bottom) consists of limestone indurated on a basalt substrate. Nannofossils are few and poorly preserved. They indicate a Pleistocene date, but insufficient taxa are present to suggest a zone: $C$. pelagicus, Gephyrocapsa spp., and $P$. discopora. Section 3-1, Piece \#7 (about $124.5 \mathrm{~m}$ sub-bottom) is also limestone on a basalt substrate. Nannofossils are few and in very poor condition. Only Gephyrocapsa spp. are identifiable, although others are present.

\section{SITE 414 \\ $32^{\circ} 03.00^{\prime} \mathrm{N}, 27^{\circ} 30.10^{\prime} \mathrm{W}$, water depth $1538 \mathrm{~m}$}

Site 414 is on Cruiser-Irving Seamount, one of the Great Meteor group of large seamounts. After a preliminary survey, a beacon was dropped on the eastern ridge. The reflection profile revealed 150 meters of sediment, but the drill bit was not able to spud in. The bottom is probably hard limestone. No sediment was recovered. The site was abandoned because Hurricane Emmy was approaching.

\section{REMARKS ON THE BIOGEOGRAPHY OF NEOGENE NANNOFOSSILS IN HIGH LATITUDES}

The diversity of nannofossil assemblages from higher latitudes (greater than $45^{\circ}$ North or South) is markedly reduced. Species present usually have long geologic ranges and cannot readily be used for stratigraphy. As a result, geological zonation of calcareous sediments in these regions is difficult, if not impossible. The zonations of Martini (1971) and Bukry (1973), although adequate for lower latitude zonation, are only partially successful in higher latitudes. Edwards and Perch-Nielsen (1975) observed that the "tropical" zones can be recognized farther north than south, at least in the North Atlantic Ocean, where the warm Gulf Stream contributes to the North Atlantic Current. As more information is learned about the biogeographic range of nannofossils with each succeeding drilling program in high latitudes, it may become possible to establish a reliable nannofossil zonation scheme useful in these regions. The answer may be a new zonation relying on datum indicators not presently recognized. Too little is presently known about nannofossil biogeography in higher latitudes to suggest a new zonation, but what has been learned can be summarized to aid in the search for a new one.

Toward this end, we offer the following remarks on the families of nannofossils occurring in high latitude sediments. Comments on the species occurring at Sites 407, 408,409 , and 410 are presented with information derived from previous investigations of high-latitude nannofossil occurrences. The systematic scheme suggested by Hay (1977) is followed here.

\section{Ceratolithaceae}

Ceratolithus: Only one specimen of $C$. cristatus was observed in Leg 49 material (Site 410$)\left(45^{\circ} \mathrm{N}\right)$. Only three other recorded instances of ceratoliths in high latitudes are reported: Leg 12 in the North Atlantic (Perch-Nielsen, 1972), Site $266\left(56^{\circ} \mathrm{S}\right)$ (Bukry, 1975a) and Site $281\left(48^{\circ} \mathrm{N}\right)$ (Edwards and Perch-Nielsen, 1975).

\section{Coccolithaceae}

Coccolithus: $C$. pelagicus is abundant in all Leg 49 material and dominates all Neogene assemblages. It has been reported in sediments as far north as $76^{\circ} \mathrm{N}$ (Müller, 1976) at Site 344 , and as far south as $77^{\circ} \mathrm{S}$ at Site 270 (Bukry, 1975a). Generally, it is the predominant species in highlatitude nannofossil oozes. Few to common $C$. eopelagicus occur at two Leg 49 sites ( 407 and 408$)\left(63^{\circ} \mathrm{N}\right)$. This species is not reported as occurring at any other sites north of $45^{\circ} \mathrm{N}$, but it occurs at several sites south of $45^{\circ} \mathrm{S}$ (Bukry, 1975a; Burns, 1975; Edwards and Perch-Nielsen, 1975).

Coronocyclus: Species of Coronocyclus were not differentiated in this study. They occur at Sites 407, 408, and 410. Perch-Nielsen (1972) noted their occurrence at some Leg 12 sites. Edwards and Perch-Nielsen (1975) found $C$. prionion at Sites $279\left(51^{\circ} \mathrm{S}\right)$ and $281\left(48^{\circ} \mathrm{S}\right)$.

Cyclicargolithus: C. floridanus is present in the lower Neogene sediments of Sites 407 and 408. Site 338 is its northernmost reported occurrence $\left(67^{\circ} \mathrm{N}\right)$ (Bukry, 1976). In the southern high latitudes it is reported as far south as $77^{\circ} \mathrm{S}$ (Site 270). It is present at many sites of Legs 28 and 29, where it dominates many of the assemblages (Bukry, 1975a, b; Burns, 1975; Edwards and Perch-Nielsen, 1975).

Cyclococcolithina: C. leptopora and C. macintyrei are present in abundance in the high latitudes of Leg 49. $C$. leptopora usually predominates when the two occur in the same assemblage; it occurs at all sites of Leg 38 as far north as $76^{\circ} \mathrm{N}$ (Müller, 1976). Both species are fairly abundant as far south as Site $278\left(56^{\circ} \mathrm{S}\right)$, their southernmost reported 
occurrence (Bukry, 1975b; Edwards and Perch-Nielsen, 1975).

\section{Discoasteraceae}

Catinaster: Neither $C$. calyculus nor $C$. coalitus were observed in Leg 49 material. Their only reported occurrence in high-latitude sediments is at Site $265\left(53^{\circ} \mathrm{S}\right)$, where they both are rare (Bukry, 1975a).

Discoaster: The diversity and abundance of discoasters in higher latitudes are substantially less than in equatorial and subtropical waters. Only where dissolution of calcium carbonate has affected all other coccoliths are discoasters concentrated in the sediments (Perch-Nielsen, 1972). Most discoasters appear to be cosmopolitan in distribution, but some species are more abundant in higher latitude, cooler waters than others; for example, $D$. exilis s.1. and $D$. variabilis s.1. (Bukry, 1971). Sediments recovered from the northernmost sites on Leg 49 , Sites 407 and $408\left(63^{\circ} \mathrm{N}\right)$, contain few to common $D$. bollii, $D$. brouweri, $D$. deflandrei, D. exilis, and $D$. variabilis, and rare $D$. calcaris, $D$. pentaradiatus, $D$. quinqueramus, and $D$. surculus. Most of these species are also reported in southern high latitudes, for example, Site $265\left(53^{\circ} \mathrm{S}\right)$ and Site $266\left(56^{\circ} \mathrm{S}\right)$ (Bukry, 1975a; Burns, 1975). The highest latitudes in which discoasters have been observed are at Sites $338\left(68^{\circ} \mathrm{N}\right)$ and $341\left(67^{\circ} \mathrm{N}\right)$, where $D$. deflandrei, D. cf. D. exilis, and D. variabilis are reported in small numbers (Bukry, 1976; Müller, 1976).

\section{Gephyrocapsaceae}

Chiasmolithus: $C$. altus was observed in rare abundance only at Site $407\left(64^{\circ} \mathrm{N}\right)$ in Leg 49 material. Perch-Nielsen (1972) reported it in abundance at Sites 116 and $117\left(57^{\circ} \mathrm{N}\right)$ in upper Oligocene sediments. Its northernmost occurrence is at Site $338\left(68^{\circ} \mathrm{N}\right)$, where it is abundant (Müller, 1976). The only other reports of its occurrence in high latitudes are in the Southern Hemisphere, where it ranges in common abundance as far south as $69^{\circ} \mathrm{S}$ at Site 274 (Bukry, 1975a; Burns, 1975).

Emiliania: E. annula (= Pseudoemiliania lacunosa) is common to abundant in the high-latitude sediments of Leg 49. It has been reported as far north as $70^{\circ} \mathrm{N}$ (Site 345) (Müller, 1976) and as far south as $56^{\circ} \mathrm{S}$ (Site 278) (Edwards and Perch-Nielsen, 1975). E. huxleyi was not observed in Leg 49 material (most likely because an electron microscope was not used to examine the samples), but it is recognized as the most ubiquitous and abundant coccolithophorid in the world's oceans (Hasle, 1960; McIntyre and Bé, 1967).

Gephyrocapsa: The four species observed in our study, $G$. aperta, G. caribbeanica, $G$. doronicoides, and $G$. oceanica, are generally common to abundant in the highlatitude sediments of Leg 49. Gephyrocapsids are reported as far north as $76^{\circ} \mathrm{N}$ (Site 344) (Müller, 1976) and as far south as $56^{\circ} \mathrm{S}$ (Site 278) (Edwards and Perch-Nielsen, 1975).

Reticulofenestra: Two species, $R$. pseudoumbilica and $R$. scrippsae, are abundant at Site $407\left(64^{\circ} \mathrm{N}\right)$. R. pseudoumbilica usually occurs in substantial numbers whenever present. It has been reported as far north as $76^{\circ} \mathrm{N}$ (Site 344) (Müller, 1976) and as far south as $65^{\circ} \mathrm{S}$ (Site 325) (Haq, 1976).

\section{Pontosphaeraceae}

Discolithina and Pontosphaera: D. vigintiforata, $P$. japonica, and $P$. multipora are all present in Site $407\left(64^{\circ} \mathrm{N}\right)$ sediments, but form a minor component of most assemblages. Their presence is seldom reported. $P$. japonica was observed at a few sites on Leg 38 (Müller, 1976). In the high latitudes of the Southern Hemisphere, Discolithina spp. and Pontosphaera spp. are generally rare where they occur (Edwards and Perch-Nielsen, 1975).

Helicopontosphaeŕa : H. kamptneri and $H$. sellii are common to abundant at many of the sites drilled in the high latitudes of the Northern Hemisphere. Both are reported as far north as $76^{\circ} \mathrm{N}$ (Site 344) (Müller, 1976). In the Southern Hemisphere, $H$. kamptneri is generally rare to few, but at one site (Site 277) $\left(56^{\circ} \mathrm{S}\right)$ it is abundant (Bukry, 1975b). Other species of helicopontosphaerids are virtually nonexistent in higher latitudes.

Scyphosphaera: Scyphosphaerids form a minor component of many assemblages in high latitudes. Their northernmost occurrence is at Site $408\left(63^{\circ} \mathrm{N}\right)$. They are only recorded at one site (Site 281$)\left(48^{\circ} \mathrm{S}\right)$ in the Southern Hemisphere (Edwards and Perch-Nielsen, 1975).

\section{Rhabdosphaeraceae}

Rhabdosphaera: $R$. clavigera and $R$. stylifera occur occasionally in high-latitude samples. They are both quite prevalent in Site 410 sediments $\left(45^{\circ} \mathrm{N}\right)$. $R$. clavigera is reported at only one site (Site 281$)\left(48^{\circ} \mathrm{S}\right)$ in the Southern Hemisphere (Edwards and Perch-Nielsen, 1975).

\section{Sphenolithaceae}

Sphenolithus: $S$. abies and S. moriformis regularly occur in many of the Leg 49 samples. S. belemnos and $S$. heteromorphus, useful for zonation of the lower and middle Miocene, are too seldom present to be relied upon consistently. S. moriformis occurs (rarely) as far north as $68^{\circ} \mathrm{N}$ (Site 338) (Müller, 1976) and as far south as $64^{\circ} \mathrm{S}$ (Site 268) (Burns, 1975). The range of $S$. abies is more restricted.

\section{Thoracosphaeraceae}

Thoracosphaera: $T$. heimii, $T$. reticulata, and $T$. saxea form a minor component of the assemblages of the highlatitude sites of Leg 49. Thoracosphaera sp. is reported as far south as Site $278\left(56^{\circ} \mathrm{S}\right)$ (Edwards and Perch-Nielsen, 1975).

\section{Triquetrorhabdaceae}

Triquetrorhabdulus: T. carinatus and T. rugosus are minor constituents of assemblages in samples from Site 407 $\left(64^{\circ} \mathrm{N}\right)$, their northernmost reported occurrence. $T$. carinatus is abundant at Sites 116 and $117\left(57^{\circ} \mathrm{N}\right)$ (PerchNielsen, 1972). T. carinatus occurs at only one southern high-latitude site (Site 278$)\left(56^{\circ} \mathrm{S}\right)$, and $T$. rugosus is reported at only three sites: Site $265\left(53^{\circ} \mathrm{S}\right)$, Site $279\left(51^{\circ} \mathrm{S}\right)$, and Site $281\left(48^{\circ} \mathrm{S}\right)$ (Bukry, 1975a; Edwards and PerchNielsen, 1975).

\section{Zygrhablithaceae}

Zygrhablithus: Z. bijugatus is common in Site 407 sediments $\left(64^{\circ} \mathrm{N}\right)$, its northernmost occurrence. It is abundant at Sites 116 and $117\left(57^{\circ} \mathrm{N}\right)$ (Perch-Nielsen, 1972). There are no reported Neogene occurrences of it in the southern high latitudes. 


\section{REFERENCES}

Bramlette, M. N. and Sullivan, F. R., 1961. Coccolithophorids and related nannoplankton of the early Tertiary in California, Micropaleontology, v. 7, p. 129-174.

Bukry, D., 1971. Coccolith stratigraphy Leg 6, Deep Sea Drilling Project. In Fischer, A. G., Heezen, C., et al., Initial Reports of the Deep Sea Drilling Project, v. 4. Washington (U.S. Government Printing Office), p. 965-1004.

1973. Coccolith stratigraphy, Eastern Equatorial Pacific, Leg 16, Deep Sea Drilling Project. In van Andel, T. H., Heath, G. R., et al., Initial Reports of the Deep Sea Drilling Project, v. 16. Washington (U.S. Government Printing Office), p. 653-712.

1975a. Coccolith and silicoflagellate stratigraphy near Antarctica, Deep Sea Drilling Project, Leg 28. In Hayes, D. E., Frakes, L. A. et al., Initial Reports of the Deep Sea Drilling Project, v. 28: Washington (U.S. Government Printing Office), p. 709-723.

1975b. Silicoflagellate and coccolith stratigraphy, Deep Sea Drilling Project, Leg 29. In Kennett, J. P., Houtz, R. E., et al., Initial Reports of the Deep Sea Drilling Project, v. 29: Washington (U.S. Government Printing Office), p. $845-872$.

1.976. Silicoflagellate and coccolith stratigraphy, Norwegian-Greenland Sea, Deep Sea Drilling Project, Leg 38. In Talwani, M., Udintsev, G., et al., Initial Reports of the Deep Sea Drilling Project, v. 38: Washington (U.S. Government Printing Office), p. 843-855.

Burns, D. A., 1975. Nannofossil biostratigraphy for antarctic sediments, Leg 28, Deep Sea Drilling Project. In Hayes, D. E., Frakes, L. A., et al., Initial Reports of the Deep Sea Drilling Project, v. 28: Washington (U.S. Government Printing Office), p. 589-598.

Dennison, J. M. and Hay, W. W., 1967. Estimating the needed sampling area for subaquatic ecologic studies, J. Paleontol., v. 41, p. 706-708.

Edwards, A. R. and Perch-Nielsen, K., 1975. Calcareous nannofossils from the southern Southwest Pacific, Deep Sea Drilling Project, Leg 29. In Kennett, J. P., Houtz, R. E., et al., Initial Reports of the Deep Sea Drilling Project, v. 29: Washington (U.S. Government Printing Office), p. 469-539.

Gartner, S., 1972. Late Pleistocene calcareous nannofossils in the Caribbean and their interoceanic correlation, Palaeogeogr., Palaeoclimatol., Palaeoecol., v. 12, p. 169-191.

Haq, B. U., 1976. Coccoliths in cores from the Bellingshausen Abyssal Plain and Antarctic Continental Rise (DSDP Leg 35). In Hollister, C. D., Craddock, C., et al., Initial Reports of the Deep Sea Drilling Project, v. 35: Washington (U.S. Government Printing Office), p. 557-567.

Hasle, G. R., 1960. Plankton coccolithophorids from the Subantarctic and Equatorial Pacific, Nytt Magasin for Botanikk, v. 8, p. 77-88.
Hay, W. W., 1961. Note on the preparation of samples for discoasterids, J. Paleontol., v. 35, p. 873.

1965. Calcareous nannofossils. In Kummel, B. and Raup, D. (Eds.), Handbook of paleontological techniques: San Francisco (W. H. Freeman and Co.), p. 3-7. 1970. Calcareous nannofossils from cores recovered on DSDP Leg 4. In Bader, R. G. et al., Initial Reports of the Deep Sea Drilling Project, v. 4: Washington (U.S. Government Printing Office), p. 455-503.

1977. Calcareous nannofossils. In Ramsay, A. T. S. (Ed.), Oceanic micropaleontology: London (Academic Press), p. 1055-1199.

Honjo, S. and Fischer, A. G., 1964. Fossil coccoliths in limestone examined by electron microscopy, Science, v. 144, p. 837839.

McIntyre, A. and Bé, A. W. H., 1967. Modern Coccolithophoridae of the Atlantic Ocean-I. Placoliths and Cyrtoliths, Deep-Sea Res., v. 14, p. 561-597.

Martini, E., 1971. Standard Tertiary and Quaternary calcareous nannoplankton zonation. In Farinacci, A. (Ed.), Plankt. Conf., 2nd, Roma, 1970, Proc., Rome (Tecnoscienza), v. II, p. 739-785.

Martini, E. and Worsley, T., 1971, Tertiary calcareous nannoplankton from the western Equatorial Pacific. In Winterer, E. L., Riedel, W. R., et al., Initial Reports of the Deep Sea Drilling Project, v. 7: Washington (U.S. Government Printing Office), p. 1471-1507.

Müller, C., 1976. Tertiary and Quaternary calcareous nannoplankton in the Norwegian-Greenland Sea, DSDP, Leg 38. In Talwani, M., Udintsev, G., et al., Initial Reports of the Deep Sea Drilling Project, v. 38: Washington (U.S. Government Printing Office), p. 823-841.

Perch-Nielsen, K., 1972. Remarks on Late Cretaceous to Pleistocene coccoliths from the North Atlantic. In Laughton, A. S., Berggren, W. A., et al., Initial Reports of the Deep Sea Drilling Project, v. 12: Washington (U.S. Government Printing Office), p. 1003-1069.

Risatti, J. B., 1973. Nannoplankton biostratigraphy of the Upper Bluffport Marl-Lower Prairie Bluff Chalk interval (Upper Cretaceous), in Mississippi. In Smith, L. A., and Hardenbol, J. (Eds.), Symposium on Calcareous Nannofossils, Proc., Gulf Coast Section, Soc. Econ. Paleont. Mineral., Houston, p. 857.

Wise, S. W., 1973. Calcareous nannofossils from cores recovered during Leg 18, Deep Sea Drilling Project: biostratigraphy and observations of diagenesis. In Kulm, L. D., von Huene, R., et al., Initial Reports of the Deep Sea Drilling Project, v. 18: Washington (U.S. Government Printing Office), p. 569-616.

Worsley, T. R., 1973. Calcareous nannofossils: Leg 19 of the Deep Sea Drilling Project. In Creager, J. S., Scholl, D. W., et al., Initial Reports of the Deep Sea Drilling Project, v. 19: Washington (U.S. Government Printing Office), p. 741-750. 